\title{
Effect of frusemide on airway smooth muscle contractility in vitro
}

\author{
A J Knox, P Ajao
}

\begin{abstract}
Frusemide, an inhibitor of sodiumpotassium-chloride ( $\mathrm{Na}-\mathrm{K}-\mathrm{Cl})$ cotransport, has been shown to inhibit the airway response to several constrictor stimuli in asthmatic subjects. The protection seen with frusemide in these studies could be due to an effect on epithelium, inflammatory cells, neural pathways, or airway smooth muscle. To determine whether frusemide inhibits airway smooth muscle contraction, experiments were performed in bovine and human airways in vitro. Fresh bovine tissue was obtained from the abattoir and human tissue from thoracotomy. The effect of $10^{-5} \mathrm{M}$ frusemide on histamine, potassium chloride, and hyperosmolar saline induced contractions was studied in bovine tracheal strips without epithelium. Frusemide, at a concentration that specifically inhibits $\mathrm{Na}-\mathrm{K}-\mathrm{Cl}$ cotransport, did not inhibit contraction caused by any of these agents. Frusemide was also without effect on hypertonic saline induced contractions of bovine and human bronchial rings with epithelium intact. These results suggest that modification of $\mathrm{Na}$ $\mathrm{K}-\mathrm{Cl}$ cotransport does not alter airway smooth muscle contractility and that the protective effect of frusemide on induced bronchoconstriction in vivo is unlikely to be due to a direct effect on airway smooth muscle.
\end{abstract}

The diuretic agent frusemide has recently been shown to protect asthmatic subjects against bronchoconstrictor stimuli when administered by nebulisation..$^{1-6}$ Studies have shown considerable protection against bronchoconstriction induced by exercise, ${ }^{1}$ ultrasonically nebulised distilled water, ${ }^{2}$ metabisulphite, ${ }^{3}$ and both the early and the late responses to antigen. ${ }^{45} \mathrm{~A}$ much smaller degree of protection was found against histamine induced constriction ${ }^{6}$ and no effect was seen on methacholine induced constriction. ${ }^{3}$ The inhibitory effects of inhaled frusemide appear to be dose related ${ }^{1}$ and the only study to look at oral frusemide showed no effect. ${ }^{1}$ Although frusemide appears to protect the airways against constrictor stimuli, none of these studies has found any appreciable effect on resting airway calibre.

The mechanism whereby frusemide exerts its protective effect has not been determined.
Frusemide is an inhibitor of sodium-potassium chloride (Na-K-Cl) cotransport, a ubiquitous transport system for mammalian cells. ${ }^{7}$ The airway response to constrictor stimuli in asthma depends on a complex series of interactions between epithelial cells, inflammatory cells and their mediators, neural pathways, and airway smooth muscle. Frusemide could thus be acting to alter epithelial function, mediator release from inflammatory cells, afferent sensory neuronal discharge, or airway smooth muscle contractility. As frusemide has been shown to inhibit vascular smooth muscle contractility, ${ }^{8}$ and signal transduction pathways in vascular and airway smooth muscle share several common features, ${ }^{910}$ we set out to determine whether the effect of inhaled frusemide seen in asthma might be due to a reduction in airway smooth muscle contractility. Inhibition of $\mathrm{Na}-\mathrm{K}-\mathrm{Cl}$ cotransport in airway smooth muscle would be expected to cause a reduction in intracellular sodium, thereby reducing intracellular calcium accumulation via $\mathrm{Na}-\mathrm{Ca}$ exchange and thus reducing contractility. ${ }^{11}$ We studied the effect of $10^{-5} \mathrm{M}$ frusemide, a concentration that specifically inhibits $\mathrm{Na}-\mathrm{K}$ $\mathrm{Cl}$ cotransport, ${ }^{7}$ on contraction caused by histamine, potassium chloride, and hypertonic sodium chloride in bovine airways. We also studied the effect of a high, non-specific concentration $\left(10^{-3} \mathrm{M}\right)$ of frusemide on hypertonic saline induced contraction in bovine airways We performed a smaller number of experiments in human airways, looking at the effect of frusemide on hypertonic saline induced contraction.

\section{Methods}

\section{PREPARATION OF TISSUE}

Fresh bovine tissue was obtained immediately after death from the local abattoir. Tissue was transported in ice to the City Hospital, where it was immediately dissected and bathed in Krebs-Henseleit solution (KHS) of the following composition (mmol/l): $\mathrm{NaCl} 118, \mathrm{KCl} 4 \cdot 7$, $\mathrm{MgSO}_{4} 1 \cdot 2, \mathrm{NaH}_{2} \mathrm{SO}_{4} 1 \cdot 2, \mathrm{CaCl} 2 \cdot 5, \mathrm{NaHCO}_{3}$ 25, glucose 11.1 (pH 7.4). Macroscopically normal lung tissue was obtained from thoracotomy specimens of patients undergoing lung resections for carcinoma and placed immediately in KHS. None of these patients had asthma but one was taking inhaled beta agonists for chronic obstructive airways disease. Two different preparations of bovine tissue were studied: tracheal strips dissected free of epithelium and connective tissue, and bron- 
chial rings dissected from 2 nd-5th order bronchi with epithelium intact. This allowed us to study responses from airway preparations with and without epithelium. In experiments using human tissue bronchial rings from 2 nd-5th order bronchi with epithelium intact were used. Bovine tracheal strips and bronchial rings were suspended under $2 \mathrm{~g}$ of tension and human bronchial rings under $1.5 \mathrm{~g}$ of tension in organ baths containing $\mathrm{KHS}$ at $37^{\circ} \mathrm{C}$, and continuously gassed with $95 \%$ oxygen and $5 \%$ carbon dioxide. These tensions had previously been shown to produce optimal repeatable responses in similar preparations. Changes in tension were recorded on four Grass FTO3 force displacement transducers (Grass Instruments, Quincy, Massachusetts) and displayed on 2 CR600 2 channel flat bed recorders (JJ Instruments, Southampton). Tissue was allowed to equilibrate under tension for one hour before each experiment.

\section{DRUGS}

Frusemide was obtained from Sigma Chemicals, Poole, and histamine acid phosphate was obtained from $\mathrm{BDH}$ Chemicals, Atherstone. Frusemide was dissolved in acetone and in all experiments appropriate concentrations of acetone were used as controls. All drug concentrations given represent organ bath concentrations.

EXPERIMENTAL PROTOCOLS

Paired preparations of approximately equal size were studied in all experiments.

\section{Bovine airways}

Histamine We studied paired tracheal strips from six animals. Histamine concentrationresponse curves (range $10^{-7}-10^{-3} \mathrm{M}$ ) were obtained with each tissue. The tissues were then washed repeatedly and allowed to return to baseline tension over one hour. Frusemide or vehicle was then added and after 15 minutes' exposure histamine concentration-response curves were again obtained.

Potassium chloride We studied paired tracheal strips from six animals. Experiments identical to the histamine experiments were performed with potassium chloride $\left(10^{-7}-10^{-1} \mathrm{M}\right)$ as the constrictor agent instead of histamine.

Hypertonic saline In each tissue studied in these experiments the contractile response to $10^{-3} \mathrm{M}$ methacholine was measured initially. The tissues were then washed repeatedly and left for one hour until tension had returned to baseline.

(a) Tracheal strips: Frusemide $\left(10^{-5} \mathrm{M}\right)$ or vehicle was added to paired preparations from six animals. After 15 minutes the KHS solution was substituted with a hypertonic KHS solution $(900 \mathrm{mmol} / \mathrm{l})$ and change in tension was measured over 30 minutes. The hypertonic solutions also contained frusemide $\left(10^{-5} \mathrm{M}\right)$ or vehicle as appropriate.

(b) Bronchial rings: Experiments identical to those performed on the tracheal strips were performed with bronchial rings from eight animals except that a $550 \mathrm{mmol} / 1 \mathrm{KHS}$ solution was used. (c) Bronchial rings with $10^{-3} \mathrm{M}$ frusemide: Experiments identical to those described in $(b)$ were performed on preparations from six animals except that $10^{-3} \mathrm{M}$ frusemide or vehicle was added to paired rings 15 minutes before the addition of hypertonic KHS (550 mmol/l).

\section{Human airways}

Hypertonic KHS Paired bronchial rings from six thoracotomy specimens were studied. The contractile response to $10^{-3} \mathrm{M}$ methacholine was measured, after which the tissues were washed repeatedly and left for one hour until tension had returned to baseline. Frusemide $\left(10^{-5} \mathrm{M}\right)$ or vehicle was then added to paired rings for 15 minutes. The KHS was then changed to hypertonic KHS (550 mmol/1) containing frusemide or vehicle as appropriate. Change in tension was observed over 30 minutes.

\section{ANALYSES}

The concentrations of histamine and potassium chloride required to produce $50 \%$ of maximum contraction $\left(\mathrm{EC}_{50}\right)$ were calculated for each preparation in the experiments using these agents. $\log _{10} E_{50}$ values were used in subsequent analyses. Change in $\mathrm{EC}_{50}$ and change in maximum tension generated after frusemide and control were compared by Student's paired $t$ test. In the hypertonic KHS experiments contraction produced by hypertonic KHS was expressed as a percentage of the maximum response to methacholine $\left(10^{-3} \mathrm{M}\right)$. Maximum hypertonic KHS induced contractions were compared in frusemide and control preparations by Student's paired $t$ test. Values of $p$ below 0.05 were regarded as significant.

\section{Results}

\section{BOVINE EXPERIMENTS}

\section{Histamine}

Frusemide had no effect on smooth muscle tension or histamine induced contraction (fig 1). Geometric mean (SEM in log units) $\mathrm{EC}_{50}$ values were $1.1 \times 10^{-5}(0 \cdot 1) \mathrm{M}$ and $4.8 \times 10^{-5}$ $(0.3) \mathrm{M}$ before and after frusemide and $1.4 \times 10^{-5}(0 \cdot 1) \mathrm{M}$ and $2.0 \times 10^{-5}(0 \cdot 1) \mathrm{M}$ before and after vehicle in control preparations. Change in $\mathrm{EC}_{50}$ after frusemide and vehicle was not significantly different $(p=0 \cdot 3)$. The mean (SEM) maximum tension generated was $110 \%$ $(6 \%)$ of the initial histamine response after frusemide and $120 \%(12 \%)$ in control strips $(p=0 \cdot 3)$.

\section{Potassium chloride}

Frusemide had no effect on potassium chloride induced contraction (fig 2). Geometric mean (SEM in log units) $\mathrm{EC}_{50}$ values were $3.8 \times 10^{-2}$ $(0.05) \mathrm{M}$ and $4.7 \times 10^{-2}(0.1) \mathrm{M}$ before and after frusemide and $4.2 \times 10^{-2}(0.05) \mathrm{M}$ and 4.7 $\times 10^{-2}(0 \cdot 1) \mathrm{M}$ before and after vehicle in control preparations. Changes in $\mathrm{EC}_{50}$ after frusemide and after vehicle were not significantly different $(p=0.4)$. The mean (SEM) maximum tension generated was $108 \%(16 \%)$ of the initial potassium chloride response after frusemide and $113 \%(11 \%)$ in control strips (p $=0.4$ ). 

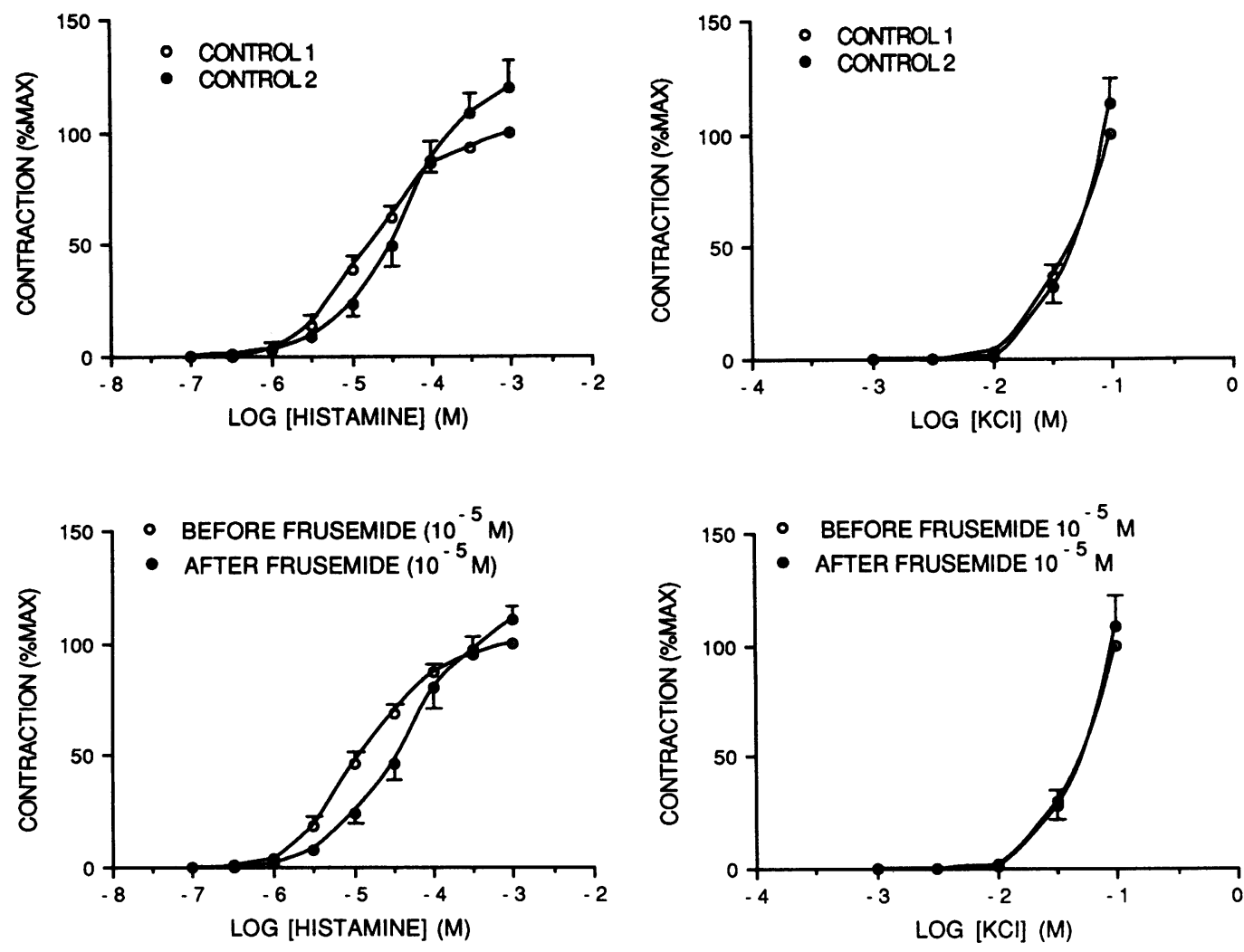

Figure 1 Histamine concentration-response curves before and after frusemide compared with repeat histamine concentration-response curves in control strips. Values shown are the means (with SEM) of six experiments in bovine tracheal strips without epithelium.

Figure 2 Potassium chloride $(\mathrm{KCl})$ concentrationresponse curves before and after frusemide compared with repeat KCl concentration-response curves in control strips. Values shown are the means (with SEM) of six experiments in bovine tracheal strips without epithelium.

\section{Hypertonic KHS}

Both concentrations of hypertonic KHS caused contraction that reached a maximum after about 15 minutes. Contractions produced by hypertonic KHS in the presence of frusemide and vehicle are shown in the table. Frusemide did not inhibit hypertonic KHS induced contractions significantly in the tracheal strips or in the bronchial rings with epithelium intact.

\section{HUMAN EXPERIMENTS}

Hypertonic KHS

Hypertonic KHS caused contraction as in the bovine experiments. The contractions produced by hypertonic KHS in the presence of frusemide and of vehicle were not significantly different (table).

\section{Discussion}

The aim of these studies was to determine whether the protective effect of frusemide on

Effect of frusemide on hypertonic KHS induced contraction *

\begin{tabular}{|c|c|c|c|c|c|}
\hline \multirow{2}{*}{$\begin{array}{l}\text { Type of } \\
\text { preparation }\end{array}$} & \multirow{2}{*}{$\begin{array}{l}\text { Hypertonic } \\
\text { solution } \\
\text { used } \\
(\mathrm{mmol} / \mathrm{l})\end{array}$} & \multirow{2}{*}{$\begin{array}{l}\text { Frusemide } \\
\text { concentration }\end{array}$} & \multicolumn{2}{|c|}{$\begin{array}{l}\text { Mean }(S E M) \\
\text { contraction }{ }^{\star}\end{array}$} & \multirow[b]{2}{*}{$p$} \\
\hline & & & Frusemide & Control & \\
\hline $\begin{array}{l}\text { Bovine tracheal strips (no EPI) } \\
\text { Bovine bronchial rings (EPI) } \\
\text { Bovine bronchial rings (EPI) } \\
\text { Human bronchial rings (EPI) }\end{array}$ & $\begin{array}{l}900 \\
550 \\
550 \\
550\end{array}$ & $\begin{array}{l}10^{-5} \mathrm{M} \\
10^{-5} \mathrm{M} \\
10^{-3} \mathrm{M} \\
10^{-5} \mathrm{M}\end{array}$ & $\begin{array}{l}74(11) \\
31(4) \\
28(5) \\
48(13)\end{array}$ & $\begin{array}{l}74(11) \\
33(4) \\
31(4) \\
54(13)\end{array}$ & $\begin{array}{l}0.9 \\
0.6 \\
0.5 \\
0.6\end{array}$ \\
\hline
\end{tabular}

^Expressed as a percentage of the maximum methacholine response. EPI-epithelium intact; no EPI-epithelium removed.

bronchoconstrictor challenge tests in asthmatic subjects reported recently ${ }^{1-6}$ was due to an effect on airway smooth muscle contractility. We studied the effect of frusemide on the contractile response to several agents that act through different pathways. Histamine acts by binding to $\mathrm{H}_{1}$ receptors and activating the inositol phosphate second messenger system. Cleavage of membrane inositol bisphosphate in response to histamine leads to production of inositol trisphosphate and diacylglycerol. Inositol trisphosphate is responsible for initiating contraction by releasing calcium from internal stores and diacylglycerol, by activating protein kinase $C$, is responsible for maintaining contraction. ${ }^{1012}$ Potassium chloride acts by causing membrane depolarisation, resulting in the influx of calcium via the voltage dependent calcium channel. ${ }^{13}$ Hypertonic saline contracts airway smooth muscle as a result of its osmotic properties, though the precise mechanism is not understood. ${ }^{14}$

We did not find any effect of $10^{-5} \mathrm{M}$ frusemide on the contractile response produced by any of these stimuli in bovine tracheal smooth muscle strips without epithelium. This concentration specifically inhibits $\mathrm{Na}-\mathrm{K}-\mathrm{Cl}$ cotransport, ${ }^{7}$ so our findings suggest that the activity of $\mathrm{Na}-\mathrm{K}-\mathrm{Cl}$ cotransport in airway smooth muscle is not an important determinant of contractility. We initially studied the effect of $10^{-5} \mathrm{M}$ frusemide on contractions induced by hypertonic KHS (900 $\mathrm{mmol} / \mathrm{l}$ ) in bovine tracheal strips without epithelium and saw no effect. Bovine tracheal 
smooth muscle has a thick layer of connective tissue separating it from epithelium, so by stripping the epithelium and connective tissue we are confident that the epithelial layer was completely removed. We considered whether the lack of effect of frusemide might have been due to the high osmolarity of the solution used and performed subsequent experiments with a lower concentration $(550 \mathrm{mmol} / \mathrm{l})$ of hypertonic KHS in bovine bronchial rings. We were careful to leave the epithelium intact in these experiments to determine whether frusemide could be acting to release a relaxant factor from airway epithelium. Frusemide can release dilator prostaglandins from vascular endothelium ${ }^{15}$ and a similar effect on airway epithelium could explain its effect in asthma. Frusemide was without effect, however, in bovine bronchial rings with epithelium intact, which suggests that the mechanism of action of frusemide in vivo is unlikely to be release of dilator prostaglandins from airway epithelium. As the concentration of frusemide $\left(10^{-5} \mathrm{M}\right)$ used in these experiments specifically inhibits $\mathrm{Na}-\mathrm{K}-\mathrm{Cl}$ cotransport, we performed further experiments with a higher concentration of frusemide $\left(10^{-3} \mathrm{M}\right)$, which would be expected to have several non-specific effects, but were again unable to find any reduction in airway smooth muscle contractility. We performed a more limited number of experiments in human bronchial rings, but the results of these experiments using hypertonic KHS were no different from those of the bovine experiments.

Our results suggest therefore that the effect of frusemide seen by other workers in asthmatic subjects in vivo is not due to an effect on airway smooth muscle contractility. Although most of our experiments were performed in bovine airways, when we compared the effect of frusemide on airway responses to hypertonic KHS in bovine and human airways we found no evidence of any species differences. The lack of effect in preparations that were not stripped of epithelium suggests that relaxant factor release from airway epithelium is not responsible for frusemide's actions in vivo. Possibly, however, damage to epithelium in our preparations prevented us from seeing any effect, though we took great care to try to avoid this. Moreover, we studied the effect of frusemide on the contractile response to only one agent (hyperosmolar KHS) in airway preparations with intact epithelium and it could be argued that we might have seen an effect had we performed experiments with histamine or potassium chloride in preparations with epithelium intact. This would seem unlikely as the protective effect of frusemide noted by Bianco and colleagues in asthmatic subjects in vivo appears to be greatest against osmotic stimuli, protection against histamine induced constriction being relatively small. ${ }^{126}$

Other mechanisms must therefore be considered to explain the effect of frusemide in asthma. Frusemide could be modifying epi- thelial function by other mechanisms. Frusemide inhibits sodium and chloride influx via the $\mathrm{Na}-\mathrm{Cl}$ cotransport system on the basolateral surface of airway epithelium, thus reducing sodium and chloride secretion into the airway lumen. ${ }^{15} 16$ The resulting alteration in ionic gradients could protect inflammatory cells against osmotic insults, thus reducing mediator release, or it might alter discharge from sensory neurones, thereby modifying neurogenic inflammation. In our experiments hypertonic solutions had direct access to the subepithelial tissues and an effect dependent on an intact epithelial barrier would not therefore have been seen. Further studies to determine the mechanism of action of frusemide are required as they may aid our understanding of the pathophysiology of asthma and allow us to develop new therapeutic agents.

We thank Mason Bros, Nottingham, for providing us with bovine tissue and Professor JSP Jones, $\mathrm{Mr}$ WE Morgan, and $\mathrm{Mr}$ FD Salama at the City Hospital for their help in providing us with human tissue. We also thank Professor A E Tattersfield for her helpful comments and the Asthma Research Council for her helpful commer

1 Bianco S, Vaghi A, Robuschi M, Pasargiklian M. Prevention of exercise-induced bronchoconstriction by inhaled frusemide. Lancet 1988;ii:252-5.

2 Robuschi M, Vaghi A, Gambaro G, Spagnotto S, Bianco S Inhaled furosemide $(F)$ is highly effective in preventin ultrasonically nebulised water $\left(\mathrm{UNH}_{2} \mathrm{O}\right)$ bronchoconstriction. Am Rev Respir Dis 1988;137(4 part 2):412.

3 Nichol GM, Alton EWFW, Nix A, Geddes DM, Chung KF, Barnes PJ. Effect of inhaled frusemide on metabisulphite and methacholine induced bronchoconstriction and nasa potentials in asthmatic subjects [abstract]. Thorax 1989 44:851P.

4 Bianco S, Pieroni MG, Refini M, Sturman A, Robuschi M. Inhaled furosemide $(F)$ prevents allergen induced bronchoconstriction in atopic asthmatics. Am Rev Respir Dis 1988;137(4 part 2):27.

5 Bianco S, Pieroni MG, Refini RM, Rottoli L, Sestini P. Protective effect of inhaled furosemide on allergeninduced early and late asthmatic reactions. $N$ Engl J Med 1989;321:1069-73.

6 Vaghi A, Robuschi M, Berni F, Bianco S. Effect of inhaled furosemide $(F)$ on bronchial response to histamine $(H)$ in asthma [abstract]. Eur Respir $J$ 1988;1(suppl 2):406S.

7 Chipperfield AR. The Na-K-Cl cotransport system. Clin Sci 1986;71:465-76.

8 Deth RC. Influence of furosemide on rubidium 86 uptake and alpha-adrenergic responsiveness of arterial smooth muscle. Blood Vessels 1987;24:321-33.

9 Hall IP, Chilvers ER. Inositol phosphates and airway smooth muscle. Pulm Pharmacol 1989;2:113-20.

10 Van Breemen C, Saida K. Cellular mechanisms regulating $\left[\mathrm{Ca}^{2+}\right]$ in smooth muscle. Annu Rev Physiol 1989;51: 315-29.

11 Van Breemen C, Aaronson P, Lowtzenhiser R. Sodiumcalcium interactions in mammalian smooth muscle. Pharmacol Rev 1979;30:167-208.

12 Rasmussen $\mathrm{H}$, Takuwa Y, Park S. Protein kinase $\mathrm{C}$ in the regulation of smooth muscle contraction. FASEB $J$ 1987;1:177-85

13 Advenier C, Cerrina J, Duroux P, Floch A, Renier A. Effects of five different organic calcium antagonists on guinea-pis isolated trachea. Br J Pharmacol 1984;82:727-33.

14 Jongejan RC, De Jongste JC, Raatgeep HC, Bonta IL, Kerrebijn KF. Constriction of isolated human airways to hypertonic krebs buffer: pharmacological characterisation of the response [abstract]. Thorax 1988;43:835P.

15 Lundergan CF. Effect of cyclooxygenase inhibition on the pulmonary vasodilator response to furosemide. J Pharmacol Exp Ther 1988;246:102-6.

16 Widdicombe JH, Nathanson IT, Highland E. Effects of loop diuretics on ion transport by dog tracheal epithelium. $A m$ J Physiol 1983;245:C388-96.

17 Welsh MJ. Inhibition of chloride secretion by furosemide in canine tracheal epithelium. J Membr Biol 1983;71:219-26. 